\section{IQ guru talks to Skeptic magazine? Given the chance to explain how he chose to endure denunciation for 'fascism', psychologist Arthur Jensen holds his peace}

\author{
Intelligence, Race, and Genetics: Conversations \\ with Arthur R Jensen \\ F Miele \\ Westview Press, Oxford. 2002; 236 pp. \\ $£ 16.99$, hardback. ISBN 0-8133-4008-X \\ Reviewed by Chris Brand
}

Heredity (2003) 90, 346-347. doi:10.1038/sj.hdy.6800226

In 1969, Arthur Jensen (today Emeritus Professor at Berkeley) began his career of martyrdom with his Harvard Educational Review article saying that educability, IQ and race were probably genetically linked. Through the ensuing 34 years of the West's tenured intellectuals suppressing the 'Jensenist Heresy', IQ became unmentionable in the media (except when excusing some wretched murderer from severe punishment); and race, too, vanished from the screen (except in assertions that, because of interbreeding, it was 'meaningless as a scientific concept'). Books by hereditarian psychologists, including Jensen himself, became unpublishable, except by mail order houses. Meanwhile, Britain's New Labour governments of 1997-2002 sensibly adopted the Jensenist idea of providing specialized academies for relatively gifted children yet gave no word of thanks to the vilified Jensen. More such intellectual thefts will occur soon as the West adapts to in vitro fertilization and genetic engineering - for the idealistic left will certainly wish to be well represented on ethics committees and to try to harness genetics to egalitarianism (making sure that procreation is used to restrict the range of IQs and enable the long-wished de facto equality of mankind).

Given Jensen's experience of a cruel world, what could 'Conversations with Arthur R Jensen' be hoped to reveal? First, why did Jensen decide to join his London mentor, Hans Eysenck, in audaciously championing genetic factors in psychology? Had Jensen's Jewishness (on his mother's side) given him some special perspective on the world? Had Jensen seen siblings - even adoptive siblings - turn out very differently from himself despite having the same family environment? Had he been shocked at the psychiatric stigmatization endured by couples of the 1950s who had an autistic child? Sadly, Frank Miele's book gives no answer. Worse, it doesn't ask the questions. Apparently, Jensen chose psychology while a California student after he found he could expect only to be second-class as a clarinettist; but just why he should have felt motivated, as he now attests, to 'bring psychology more fully into the larger domain of biology' (p 169) remains unknown. Did Jensen have a political agenda? If so, he stonewalls Miele - and anyhow claims to be content that America should have a sizeable welfare state that will long continue to support the country's Black underclass.

Who were Jensen's friends in martyrdom and what was the organization of the London School of which he became the revered intellectual head? (The journal Intelligence recently devoted a Special Issue to him, calling him 'A King among Men.') What was the plan of campaign for dealing with the rise of political correctness which was making even discussion of race impossible? Miele's book has no index allowing tracing, but such crown princes of the London School as Phil Rushton (who first linked the Mongoloid-Caucasian-Negroid continuum to a wide range of psychological features, including sexuality - Rushton, 1985) and Richard Lynn (who first noticed evidence that Black African IQ was actually only 70 - Lynn, 1991) certainly do not loom large in Jensen's 'conversation.' Scrupulously aiming to avoid controversy, the man who first so sensationally attracted it now disdains any interesting propositions about the human condition. Jensen even says he does not feel either 'inclined or properly qualified' to think through the political implications of his work.

Lastly, what about Arthur Jensen's enemies? (One of them, the author of the brazenly anti-IQ book, The Mismeasure of Man (Gould, 1981), became President of the American Academy for the Advancement of Science while Jensen himself reeled through eight publishing houses before finding a taker for his The $g$ Factor: the Science of Mental Ability.) Were Jensen's fanatical foes all Jewish Marxists who knew themselves to be veritable high priests of the dogmas of political correctness which expressed leftists' ambitions after supertaxes, council housing and nationalization had to be dropped? Astonishingly, Jensen says he has simply no idea. In three decades of hard fighting, he made no study whatever of his opponents - Leon Kamin, Jerry Hirsch, the late Stephen Jay Gould, Richard Lewontin, Barry Mehler and Britain's Steven Rose and Steve Jones - even when Mehler stamped on the once leading hereditarian, Raymond Cattell, in his dotage, denying that nonagenarian psychometrician-psychologist the Lifetime Achievement Award of the American Psychological Association (eg New York Times, 15 viii 1997; Chicago Tribune, 17 viii 1997). Jensen himself says he is politically naïve as if this can be an excuse. He evidently forgets Aristotle's opinion that, under reasonably democratic institutions, politics would be one of the higher expressions of human nature. Conversationalist Miele should never have tolerated Jensen's evasions. As it is, Miele does not even ask when, if ever, Jensen stopped voting Democrat. Miele is convinced of Jensen's 'Gandhian dedication to following principle'; but we are not told what the principle is, nor how it triumphed over other principles, nor how it was pragmatically pursued. The only flash we are given is of the young Jensen's being thrown out of Sunday School because of 'argumentativeness and resistance to accepting things on faith.' There is no mention of Jensen's longstanding membership of Britain's Eugenics Society (today the Galton Institute). All this is par for a course where Miele won't explore why the tender-minded Jensen turned in 1956 
from psychoanalysis and projective tests to toughminded psychometric psychology, but it is still a grave disappointment.

Instead of answering these interesting questions, Miele's e-mailed conversations with Jensen provide a polite trot around familiar psychogenetic territory - or several trots, because Miele feels obliged to introduce each conversation by summarizing it, and then repeating himself in his direct questions to his interviewee; and Jensen - himself no stranger to repetition - then rehearses the arguments once more, but without the precise quantification for which he is rightly famous (and without ever distinguishing narrow from broad heritability or saying why monochorionic identical twins diverge in the womb - thanks to the normal ferocities of sibling competition for maternal resources). Jensen is also poor on race, thinking it a 'fuzzy, open-ended, arguable' concept rather than seeing that race is nothing other than a substantially inbred line of descent - with very few people of the past or present being 50-50 mixes of the main racial groups. Certainly, Miele attempts a little fast bowling. But how can you bowl fast and catch someone off guard in e-mail? Sadly, this whole exercise is misconceived. Fans of the mighty Jensen should tell students to read his own fine popularization of his ideas in his Straight Talk About Mental Tests (Jensen, 1981) although students will have to use libraries because the book is out of print thanks to Jensen, with his high scholarship, having entirely failed to orchestrate opposition to the domination of social science and the media by believers in 'the blank slate.' As for fans themselves, they can look forward to the new Festschrift for Jensen, The Scientific Study of Intelligence, to be published by Pergamon in 2003.

\section{References}

Gould SJ (1981). The Mismeasure of Man. Norton: New York. Jensen AR (1981). Straight Talk about Mental Tests. Free Press: New York.

Lynn R (1991). Race differences in intelligence: a global perspective. Mankind Q 31: 255-296.

Rushton JP (1985). Differential $K$ theory: the sociobiology of individual and group differences. Personality and Individual Differences 6: 441-452.

Chris Brand

E-mail: brand@crispian.demon.co.uk 